\title{
KOLABORASI PARA PIHAK DALAM PENANGANAN DESTINASI WISATA TERDAMPAK BENCANA DITAMAN NASIONAL GUNUNG RINJANI
}

\author{
Stakeholder Collaboration in Handling Disaster-Based Tourism Destination \\ in The Rinjani Mountain National Park
}

\section{Yumantoko'}

\begin{abstract}
Indonesia is in the ring of fire which makes it prone to disasters such as earthquakes and volcanic eruptions. Even though it is in the danger zone, the handling of disasters is still not optimal, with still a lot of negative news about the handling carried out. In 2018, Lombok experienced an earthquake in which one of the most affected area was tourist destination of Mount Rinjani National Park. This paper aims to explore the role of relevant stakeholders in handling disasters, especially in the tourist sites of Mount Rinjani National Park. Data is obtained through online media related to disaster management in the Mount Rinjani National Park region. The results show that the disaster is carried out in the three stages, namely pre-disaster, disaster stage, and rehabilitation and reconstruction stage. In the pre-disaster stage, local agencies played a lot of roles in mitigation activities whereas when disaster occurs central agencies played more roles in emergencies. During the period of rehabilitation and reconstruction, the central agency becomes the leader in restoring the affected destinations to become normal againy.
\end{abstract}

Keywords : earthquake, disaster, tourism, stakeholder, Mount Rinjani National Park

\begin{abstract}
ABSTRAK
Indonesia berada di wilayah ring of fire yang menjadikannya rawan bencana seperti gempa, dan letusan gunung berapi, akan tetapi selama ini penanganan bencana masih belum maksimal dengan masih banyaknya berita negatif tentang penanganan yang dilakukan. Pada 2018, Lombok mengalami gempa yang salah satu daerah terdampaknya adalah destinasi wisata Taman Nasional Gunung Rinjani. Tulisan ini bertujuan untuk menggali peran para pihak terkait dalam penanganan bencana terutama di lokasi wisata Gunung Rinjani. Data diperoleh melalui media online yang terkait tentang penanganan bencana di Wilayah Gunung Rinjani. Hasil menunjukan bahwa penanganan bencana dilakukan dalam tiga tahap yaitu pra bencana, ketika bencana, serta rehabilitasi dan rekonstruksi. Dalam tahap pra bencana instansi lokal banyak berperan dalam kegiatan mitigasi, sedangkan ketika bencana terjadi instansi pusat lebih banyak berperan dalam keadaan darurat. Sedang dalam masa rehabilitasi dan normalisasi instansi pusat menjadi pemimpin dalam pemulihan kembali destinasi yang terdampak agar menjadi normal kembali.
\end{abstract}

Kata Kunci : gempa bumi, bencana, pariwisata, para pihak, Taman Nasional Gunung Rinjani

Author Institution $\quad$ : ' Mahasiswa Program Pascasarjana Sosiologi, Fakultas Ilmu Sosial dan Ilmu Politik, Universitas Gajah Mada - Jalan Sosio Yustisia No. I, Karang Malang, Caturtunggal, Kec. Depok, Kabupaten Sleman, Daerah Istimewa Yogyakarta 5528I

Koresponding Author : Tel.6281804054433; Email: 'yumant@gmail.com

Articel History : Received 16 January 2019; received in revised from 08 April 2019; accepted 08 April 2019; Available online since 30 April 2019

\section{PENDAHULUAN}

Bencana alam seperti gempa bumi dan gunung meletus tidak dapat diprediksi kedatangannya. Sejak dahulu bencana tersebut merupakan peristiwa alam yang banyak menelan kerugian materil dan non materil. 
Indonesia berada di wilayah ring of fire yang terdapat tiga buah lempeng aktif yaitu IndoAustralia di selatan, Eurasia di utara dan Pasifik di timur menghasilkan lebih dari 70 sesar aktif dan belasan zona subduksi yang rawan gempa dan gunung meletus (Iswidodo, 2019). Kejadian bencana seperti itu akan terus muncul tanpa diketahui waktunya.

Salah satu contoh gempa bumi yaitu di Lombok yang terjadi pada bulan Juli hingga Oktober 2018 menyebabkan kerugian materil sebesar 8,8 Triliun Rupiah (Rachman, 2019) serta korban meninggal sebanyak 555 jiwa dan mengungsi 390.529 orang (Septia, 2019). Pulau Lombok yang sebagian besar masyarakatnya tergantung pada sektor pariwisata menjadi terganggu kehidupannya karena gempa. Misalnya saja Taman Nasional Gunung Rinjani (TNGR) yang sebelum gempa mendapat banyak kunjungan baik dari turis dalam negeri maupun mancanegara, namun setelah gempa, tercatat nol pengunjung karena ditutup untuk beberapa waktu. Pada tahun 2017 jumlah wisatawan yang berkujung ke Nusa Tenggara Barat tercatat sebanyak 3,5 juta orang, I,5 juta di antaranya merupakan wisatawan mancanegara (bbc.com, 20l8). Jika tidak ditangani secara cermat, bencana di Gunung Rinjani dapat mengancam pariwisata Lombok secara khusus dan Indonesia secara umum.

Bencana alam merupakan kejadian tidak terduga yang sering terjadi di Indonesia. Akan tetapi penanganannya masih tergolong belum optimal. Bencana akan mendatangkan kondisi buruk bagi masyarakat terdampak seperti tidak terurusnya pengungsi, tempat pengungsian yang tidak layak, kekurangan makanan, kekurangan tenda, listrik padam, kekurangan air bersih, jalan rusak, balita yang terlantar, kesulitan akses kesehatan, informasi yang tidak lengkap dan bahkan kadang terjadi penjarahan. Seharusnya pihak terkait mampu belajar dari waktu kewaktu bagaimana penanganan semestinya ketika bencana datang. Bangsa Indonesia adalah bangsa yang tinggal di atas bencana. Untuk itu diperlukan kelembagaan yang sudah terbentuk untuk mengatasi bencana secara spontan jika terjadi bencana. Akan tetapi dalam pelaksanaannya tidak mudah dilakukan karena kondisi dan tingkat kerusakan bencana yang beragam.

Tulisan ini membahas tentang upaya para pihak pariwisata dalam mengurangi dampak gempa bumi di Lombok khususnya di kawasan wisata Gunung Rinjani. Peran para pihak ketika terjadi bencana seharusnya menjadikan bencana tidak memberi efek buruk kepada warga setempat. Penanganan bencana membutuhkan kolaborasi dari banyak aktor agar cepat dan tuntas. Penelitian ini secara khusus akan menjelaskan secara teoritis tentang penanganan bencana yang dikembangkan oleh Ritchie (2004) ke dalam masa sebelum bencana, ketika bencana, dan pada masa rehabilitasi dan rekonstruksi.

\section{METODE PENELITIAN}

Penelitian ini merupakan penelitian desk study yang menganalisis data sekunder kualitatif dari media online. Dalam beberapa tahun terakhir penelitian yang menggunakan data digital tumbuh pesat seiring perkembangan teknologi komunikasi dan informasi (Corti \& Fielding, 20I6). Data online dapat dijadikan rujukan sebagai data dalam penelitian sosial. Banyak penelitian yang menggunakan data online sebagai sumber datanya misalnya penelitian Dougall, Horsley, \& McLisky (2008) yang meneliti tentang komunikasi ketika bencana di Indonesia. Wang \& Ye (20I7) juga meneliti tentang penggunaan data dari sosial media untuk penelitian kebencanaan. 
Data yang muncul dari hasil pencarian mesin pencari kemudian diuji antara lain dengan : Pertama pengujian kredibilitas misalnya ketika mengamati kerusakan dengan cara membandingkan kerusakan yang terekam lewat media online dengan pengalaman observasi ketika berada di lokasi sebelum bencana. Kedua pengujian transferabilitas dilakukan dengan cara memilah informasi yang tepat lewat media online. Pada tahap awal, kami menggunakan mesin pencari Google untuk mencari sumber data. Kata kunci yang digunakan antara lain "penanganan gempa Lombok", "peran lembaga swasta dalam penanganan Lombok”, dan "peran lembaga swadaya masyarakat dalam penanganan gempa Lombok". Dari hasil yang ditampilkan mesin pencari, kami mereduksi hanya menggunakan data yang berasal dari berita online arus utama (mainstream) karena berita online seperti ini memiliki tim untuk menyeleksi dan mengolah bahan berita yang benar-benar kredibel. Selain itu, berita online diawasi oleh Dewan Pers, sehingga validitasnya tetap terjaga. Apabila hasil pencarian ditemukan lembaga tertentu dalam penanganan bencana, kami menggunakan informasi tersebut untuk menggunakan website resmi dari lembaga terkait sebagai sumber data. Ketiga pengujian dependabilitas dilakukan dengan cara menguji konsistensi pencarian menggunakan mesin pencari Google dengan kata kunci antara lain "peran lembaga dalam penanganan bencana gempa Lombok". Keempat pengujian konfirmabilitas yaitu dengan melihat hasil pencarian mesin pencari. Ketika hasil yang sama dimuat pada beberapa media online yang berbeda, ini berarti informasinya objektif.

Setelah data terkumpul, kemudian dikelompokan berdasarkan nama lembaga, serta peran lembaga dan responnya terhadap bencana. Selanjutnya data tersebut direduksi dan dikelompokan berdasarkan teori bencana dari Ritchie (2004).

\section{HASIL DAN PEMBAHASAN}

\section{A. Para pihak (Tinjauan Teoritik)}

Menurut Freeman (2010), para pihak (stakeholder) adalah sejumlah grup atau individu yang dipengaruhi atau memengaruhi sesuai tujuan organisasi. Jones dan Wicks dalam Pennington-Gray et al (2015) menyebutkan bahwa teori para pihak berfokus pada: (I) manajerial pembuat keputusan, (2) hubungan organisasi mempunyai organisasi konstituen yang berdampak pada organisasi, (3) hubungan dengan lembaga lain yang menghasilkan outcome, dan (4) kepentingan semua grup para pihak memiliki derajat yang sama. Pada bidang-bidang tertentu, para pihak terdiri dari berbagai macam organisasi yang terkait satu sama lain. Misalnya di bidang pariwisata para pihak utama yang menangani pariwisata adalah Kementerian Pariwisata Republik Indonesia yang memiliki tugas dalam mengembangkan destinasi dan industri pariwisata, pemasaran, dan kelembagaan kepariwisataan. Di bawahnya ada instansi daerah tingkat provinsi (dinas provinsi), dan instansi tingkat kabupaten (dinas kabupaten).

Penelitian ini menggunakan teori inter relationalship organization untuk membahas hubungan antar para pihak. Menurut Merton dalam Evan, (1965), teori ini berusaha untuk menjelaskan tentang konsep role-set. Role-set terdiri dari peran dan hubungan peran pada status yang melekat pada seseorang atau lembaga . Contohnya seperti, professor tidak hanya berinteraksi dengan siswa akan tetapi juga dengan professor, dekan, rektor, asosiasi dosen, dan lain sebagainya. Dalam memahami aktor yang terlibat dalam penanganan 
bencana penelitian ini menggunakan ilustrasi bahwa setiap aktor yakni para pihak dibentuk dengan tujuan yang ditetapkan. Misalnya Balai Taman Nasional Gunung Rinjani yang ditetapkan sebagai lembaga yang mengelola Taman Nasional Gunung Rinjani (TNGR) maka hanya berurusan dengan para pihak kehutanan saja. Ketika bencana datang di wilayah TNGR, balai mempunyai kewajiban untuk berkoordinasi dengan instansi lain yang menangani masalah bencana, misalnya BNPB, PMI,TNI, POLRI dan sebagainya.

Pariwisata adalah bisnis yang membutuhkan iklim kondusif. Ketika terjadi hal kecil yang mengurangi minat kunjungan wisatawan misalnya bencana maka perubahan akan cepat terjadi terutama dengan jumlah kunjungan akan menurun tajam (Ritchie, 2004). Misalnya saja erupsi Gunung Agung di Bali yang terjadi pada Tahun 2017 bukan hanya saja memengaruhi kunjungan turis ke Bali akan tetapi lokasi yang berada di sekitarnya seperti Lombok akan terkena dampaknya (suarantb.com, 2018). Keterkaitan antara satu dengan lain dalam bisnis pariwisata menjadi perhatian penting para pihak agar suatu peristiwa tidak menimbulkan berkurangnya kunjungan wisatawan. Pariwisata adalah bisnis yang berkaitan dengan pelayanan dan kenyamanan. Bencana alam dinilai sebagai hal yang mengurangi kenyamanan wisatawan ketika berkunjung ke suatu wilayah.

Bencana alam adalah hal yang berada di luar perencanaan manusia yang biasanya akan mengakibatkan kerugian baik materil dan non materil. Penanganan bencana sebagai antisipasi dampak yang lebih besar menjadi kewajiban dari para pihak yang terlibat. Salah satu strategi perencanaan tentang kebencanaan dapat dilihat sebagaimana bagan pada Gambar I (Ritchie, 2004) di bawah ini.

Berdasarkan teori yang dikemukakan
Ritchie (2004) pada Gambar I, penanganan bencana dimulai dengan membuat perencanaan yang mencakup skenario yang akan dilakukan ketika bencana terjadi, misalnya bencana yang kecil memiliki penanganan berbeda dengan bencana yang lebih besar. Perencanaan memerlukan data sejarah bencana yang menimpa lokasi tersebut. Selain itu dalam perencanaan perlu melibatkan para pihak pariwisata dan para pihak bidang kebencanaan untuk memastikan kerjasama yang dapat dilakukan untuk mengurangi dampak yang lebih besar. Organisasi lokal juga perlu dilibatkan dalam menghadapi segala macam krisis agar ketika terjadi krisis dapat menentukan langkah untuk meminimalisir kerugian di sekitar wilayah mereka.

Ketika bencana terjadi, implementasi penanganan bencana di lapangan memerlukan kesiapan dari para pihak yang terlibat di lokasi bencana. Dampak bencana memang tidak dapat diprediksi besarnya tingkat kerusakan yang akan dialami di suatu daerah. Bencana adalah sesuatu yang bersifat kompleks, dan ketika bencana terjadi bisa saja suasananya menjadi chaos dan tidak terkendali sama sekali. Akan tetapi dengan perencanaan yang telah dilakukan oleh berbagai elemen akan mampu mengurangi dampak buruk yang akan terjadi. Bisa saja pelatihan organisasi lokal dalam mitigasi bencana dapat meningkatkan partisipasi masyarakat lokal dalam mengurangi dampak yang lebih besar. Namun demikian apabila ternyata bencana yang datang lebih besar dan di luar prediksi, bisa jadi masyarakat lokal malah akan tergantung dengan pihak luar.

Langkah terakhir dalam penanganan bencana adalah evaluasi dan umpan balik untuk menuju tahap pemulihan dan menjadi normal seperti sedia kala. 


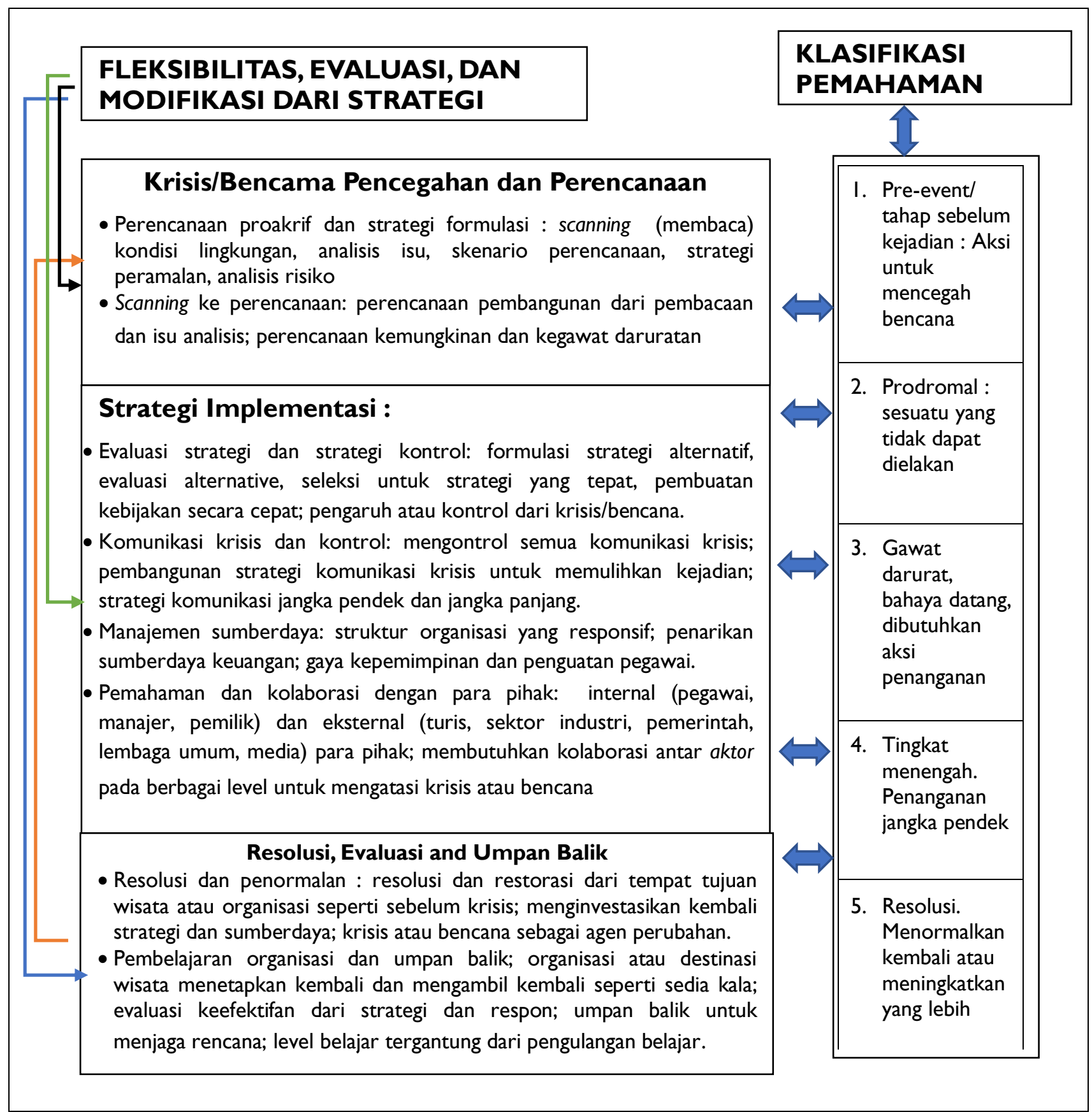

Sumber : Ritchie (2004)

Source : Ritchie (2004)

\section{Gambar I. Manajemen krisis dan bencana; strategi dan konsep kerja Figure I. Management of crises and disasters; work strategies and concepts}

Para pihak akan berupaya untuk mengurangi dampak buruk yang ditimbulkan setelah krisis meskipun kadang hal tersebut sangat sulit untuk diprediksi terutama antara besarnya bencana dengan sumberdaya tersedia yang dapat diarahkan untuk menanganinya. Kemampuan mengendalikan bencana yang terjadi di luar kemampuan para pihak dapat dihindari dengan sistem perencanaan yang baik dengan 
memperkirakan skenario tingkat bencana yang akan datang. Kepercayaan berbagai pihak terutama pengguna objek wisata akan bertambah dengan kemampuan destinasi dalam mengendalikan bencana yang terjadi di wilayahnya. Turis yang datang akan merasa aman karena mereka percaya dengan penanganan jika hal terburuk menimpa mereka akibat bencana.

\section{B. Gempa bumi dan Dampaknya bagi pariwisata di Gunung Rinjani}

Gempa bumi yang terjadi di Pulau Lombok yang diawali pada Bulan Juli 2018 kemudian terjadi secara terus menerus hingga Oktober 2018. Kekuatan gempa yang pernah tercatat maksimum mencapai 7 skala richter, sedangkan gempa susulan masih terus terjadi hingga tiga bulan sesudahnya memiliki kekuatan yang bervariasi dengan magnitudo di bawah 7 skala richter. Gempa bumi tersebut menyebabkan kerusakan hebat terutama di wilayah Lombok Utara yang dekat dengan pusat gempa. Untuk penanganan pasca gempa, Presiden mengeluarkan Inpres No. 5 Tahun 2018 tentang Percepatan Rehabilitasi dan Rekonstruksi Pascabencana Gempa Bumi yang menitikberatkan pada penanggulangan darurat pasca gempa.

Ketika Gempa terjadi, pada wilayah Taman Nasional Gunung Rinjani (TNGR) yang menjadi salah satu destinasi unggulan di Lombok, terdapat wisatawan sebanyak I.226 orang yang tengah melakukan pendakian, di mana 723 orang merupakan warga negara asing dari berbagai negara, seperti Thailand, Malaysia, Prancis, dan Belanda (bbc.com, 2018). Dari jumlah tersebut terdapat dua orang korban meninggal. Para pendaki dan pengunjung TNGR tersebut sebelumnya terperangkap di atas gunung karena jalur pendakian tertutup material longsor akibat gempa berkekuatan 6,4 pada skala Richter pada hari Minggu Tanggal 29 Juli 2018 (bbc.com, 2018).

\section{Para pihak Penanganan Bencana Bidang Pariwisata di Lombok}

I. Lembaga Lokal di Desa

Di Desa Sembalun Lawang terdapat Tim Siaga Bencana Desa (TSBD) yang terbentuk sebagai antisipasi terhadap bahaya bencana bagi masyarakat desa (bakti.or.id, 2019). Kegiatan yang bersifat mitigasi bencana lebih menjadi fokus sesuai dengan karakteristik wilayah tertentu. Dengan memiliki kesadaran terhadap bencana, warga akan memiliki ketahanan ketika bencana datang.

Hal yang dilakukan adalah meminimalisir kerugian yang dialami warga. lembaga lain yang banyak terlibat dengan lembaga lokal di tingkat desa adala Badan Penanggulangan Bencana Daerah (BPBD) atau Badan Penanggulangan Bencana Nasional (BNPB) dan lembaga pemerintahan daerah.

Berbagai macam kegiatan yang dilakukan antara lain sosialisasi melalui siaran radio. Ketika siaran radio biasanya diselipkan tentang cara menghadapi bencana. Untuk anak-anak terdapat gerakan pramuka yang menekankan pentingnya menjaga alam. Beberapa kegiatan yang sudah dilakukan adalah melakukan penanaman di sekitar desa mereka. Untuk kaum ibu-ibu kegiatan lebih menitikberatkan pada antisipasi hilangnya mata pencaharian pertanian setelah bencana. Oleh karena itu mereka diajar berbagai macam kegiatan untuk membuat makanan dari jenis bahan-bahan lokal agar nantinya dapat dijual sebagai sumber pendapatan (bakti.or.id, 2019).

2. Lembaga Swadaya Masyarakat (LSM)

Dalam Undang-undang No 24 tahun 2007, aktor utama dalam penanganan bencana 
adalah pemerintah. Lembaga Swadaya Masyarakat (LSM) dapat berkolaborasi dengan pemerintah terutama dalam mitigasi bencana (sebelum gempa), dan masa rehabilitasi di Sembalun, Konsepsi dengan salah satu programnya adalah adaptasi perubahan iklim dan pengurangan risiko bencana, dan Oxfam dengan fokus kegiatan pada keadilan gender, keadilan ekonomi, dan penanganan bencana alam, menjadi organisasi yang melakukan advokasi baik kepada masyarakat lokal maupun pemerintah setempat.

Salah satunya adalah advokasi terhadap Tim Siaga Bencana Desa. Mereka memberikan sosialisasi kepada kader-kader di tingkat lokal agar mampu berperan terhadap perubahan jika sewaktu-waktu terjadi bencana di lingkungan mereka (Jania, 2019). Ketika bencan terjadi keadaannya akan menjadi chaos, oleh karena itu lembaga ini memberikan manajemen dalam menyelesaikan permasalahan selama bencana berlangsung.

Dengan adanya Tim Siaga Bencana Desa maka secara struktural dapat melakukan koordinasi dengan pihak berwenang terkait bencana seperti BNPB/BPBD, Badan Sar Nasional (BASARNAS) dan lain sebagainya.

\section{Pemerintah Daerah}

Berdasarkan Undang-Undang No 24 tahun 2007, tanggung jawab pemerintah daerah dalam penanganan bencana antara lain : menjamin pemenuhan hak masyarakat dan pengungsi, perlindungan masyarakat dari dampak bencana; pengurangan risiko bencana dan pemaduan pengurangan risiko, dan pengalokasian Anggaran Pendapatan dan Belanja Daerah (APBD) untuk bencana. Selain itu pemerintah daerah memiliki wewenang dalam hal : penetapan kebijakan penanggulangan bencana pada wilayahnya selaras dengan kebijakan pembangunan daerah, pembuatan perencanaan pembangunan yang memasukkan unsur-unsur kebijakan penanggulangan bencana.

Pemerintah Kabupaten Lombok Timur telah mengantisipasi bencana dengan mengeluarkan Perda Nomor 3 Tahun 2012. Perda tersebut digunakan dalam penanganan bencana di wilayah Kabupaten Lombok Timur. Secara bersamaan peraturan tersebut menjadi acuan bagi para pihak dalam menyiapkan diri menghadapi bencana. Instansi tersebut antara lain Badan Penanggulangan Bencana Daerah dan BAPPEDA, Kepolisian dan TNI, Puskesmas dan Puskemas pembantu, Dinas Sosial dan Transmigrasi, Dinas Pendidikan, Unit SAR, Palang Merah Indonesia, Dinas Kesehatan, Satpol PP, dan Bakesbangpol (bakti.or.id, 2019).

4. Kementerian Lingkungan Hidup dan Kehutanan/Taman Nasional Gunung Rinjani

Balai Taman Nasional Gunung Rinjani memiliki tugas pokok mengelola wilayah taman nasional untuk keperluan konservasi sumberdaya alam hayati dan ekosistemnya berdasarkan peraturan perundangan. Hal tersebut dilakukan dengan melakukan penataan dengan perencanaan, pelaksanaan, dan evaluasi program di wilayah taman nasional (Balai Taman Nasional Gunung Rinjani, 2019). Ketika gempa terjadi, wilayah taman nasional mengalami kerusakan terutama di area pendakian. Taman Nasional menutup jalur pendakian sehingga turis tidak dapat masuk lokasi sampai dengan selesainya perbaikan tracking. Pada tahap tanggap darurat, Taman Nasional Gunung Rinjani 
melakukan koordinasi dengan BNPB, BPPD, TNI, POLRI untuk melakukan evakuasi terhadap korban meninggal di jalur pendakian. Selanjutnya TNGR bersama para pihak lain memperbaiki lokasi wisata agar dapat digunakan secara aman untuk pendakian. Para pihak yang dimaksud antara lain TNI, Polri, Basarnas, Dinas Pariwisata Provinsi NTB, Dinas Pariwisata Kabupaten Lombok Utara dan Lombok Timur, BPBD Kabupaten Lombok Utara dan Lombok Timur, Perwakilan Trek Organizer Senaru dan Sembalun, perwakilan pemandu, porter, dan Edelweis Medical Help Center (EMHC) (mongabay.co.id, 20l8). Jalur pendakian tidak dapat digunakan hingga tahun 2020 sehingga masyarakat yang sudah tergantung dengan sektor pariwisata seperti guide dan agen travel kehilangan potensi pendapatan. Untuk itu Balai Taman Nasional Gunung Rinjani mencarikan sumber pendapatan dari pekerja sektor pariwisata dengan dengan mengalihkan wisatanya ke air terjun Mangku Sakti, Air Berik, Air Terjun Kembang Kuning, Senaru, dan Sendang Gile (Senja, 2019).

\section{Kementerian Pariwisata}

Salah satu tugas dari Kementerian Pariwisata adalah perumusan dan penetapan kebijakan di bidang pariwisata (Kementerian Pariwisata RI, 2019). Dalam penanganan bencana, Kementerian Pariwisata lebih mementingkan aspek mitigasi (Dimyati, 2019). Untuk itu Kementerian Pariwisata sudah menyiapkan langkah antisipasi agar destinasi wisata ketika terkena bencana tidak menimbulkan efek negatif berkepanjangan.

Kerusakan parah akibat gempa bumi terjadi di Gili Trawangan, Gili Meno, Gili Air, Kawasan Senaru, Kawasan Desa Wisata Kerta Gangga, Wisata Krujuk, Mall Epicentrum, Kawasan Trekking Rinjani, Air
Terjun Benang Kelambu, Air Terjun Benang Stukel, dan Pura Penataan Agung Rinjani Kecamatan Bayan (Soenarso , 2019). Untuk itu, Kementerian Pariwisata telah membuat program Lombok Bangkit dengan tujuan agar pariwisata di Lombok dapat segera bangkit seperti sedia kala sebelum bencana. Tidak semua wilayah di Lombok mengalami kerusakan parah akibat gempa. Di wilayah Mandalika yang juga merupakan tempat favorit wisata di Lombok tidak begitu terasa dampak gempa bumi jika dibanding dengan daerah destinasi di Lombok Utara dan Lombok Barat. Untuk itu, promosi wisata dilakukan pada daerah yang tidak berdampak parah gempa dengan strategi branding, advertising, dan selling (BAS), untuk menginformasikan secara akurat kondisi dan situasi terkini kepada publik dan media (Kurniawan, 2019).

Beberapa hal yang dilakukan oleh Kementerian Pariwisata dalam menangani pariwisata yang terkena dampak bencana antara lain: Pertama, Melakukan trauma healing kepada pihak yang mengalami bencana agar korban bencana dapat cepat bangkit untuk membangun. Trauma healing dilakukan oleh banyak relawan dari berbagai organisasi termasuk TNI dan Polri; Kedua melakukan koordinasi dengan OJK (Otoritas Jasa Keuangan) dalam pengurangan bunga pinjaman agar usaha yang sempat terputus akibat bencana dapat segera bangkit; ketiga pemulihan destinasi. Misalnya melakukan koordinasi dengan pemangku kepentingan dalam pemulihan sarana dan prasarana penunjang pariwisata misalnya jalan, pelabuhan, jembatan, listrik dan air agar segera dapat diperbaiki; keempat yaitu pemasaran. Promosi pariwisata pasca terjadi bencana dianggarkan sebesar Rp20 miliar (Reza, 2019). 
6. Badan Penanggulangan Bencana Daerah (BPBD)/Badan Nasional Penanggulangan Bencana (BNPB)

Peran yang telah dilakukan oleh BNPB adalah sebagai koordinator ketika bencana terjadi. BNPB mengkoordinasikan dengan semua pihak terkait becana terutama dalam proses sebelum bencana, tanggap darurat, dan rehabilitasi rekonstruksi bencana (BNPB, 2019).

Pada tahap awal BNPB sudah membangun rambu-rambu evakuasi untuk jalur evakuasi masyarakat. Selain itu BNPB bekerjasama dengan hotel-hotel di Lombok untuk membuat rambu-rambu bencana. BNPB juga melatih banyak instansi mulai dari swasta, komunitas lokal, instansi pemerintah, dan sebagainya untuk peka terhadap bencana. Ketika bencana berlangsung, BNPB bersama lembaga lain mengevakuasi korban baik yang selamat maupun meninggal dunia (Anisa, 2019).

\section{Basarnas, TNI/POLRI, PVMBG}

Untuk evakuasi, penyelamatan korban membutuhkan instansi yang memiliki pengetahuan penanganan darurat dan berpengalaman di lapangan. Instansi tersebut yaitu Badan SAR Nasional (Basarnas), Tentara Nasional Indonesia (TNI) dan Kepolisian Republik Indonesia (POLRI) melakukan kolaborasi dalam mengevakuasi korban yang masih berada di jalur pendakian. Keberadaan mereka dalam membantu penanganan bencana sangat memudahkan proses evakuasi korban bencana. Pusat Vulkanologi dan Mitigasi Bencana Geologi (PVMBG) mengomunikasikan hasil pengamatannya kepada pelaku kepentingan tentang informasi terkini aktivitas geologi di sekitar Gunung Rinjani (bbc.com, 20l8).
8. Perhimpunan Hotel dan Restoran Indonesia (PHRI) NTB

Perhimpunan Hotel dan Restoran Indonesia (PHRI) membantu wisatawan yang terkena bencana dengan membantu dan memberi rasa nyaman. Beragam fasilitas gratis diberikan dari penginapan, makanan hingga transportasi. Kenyamanan dan keamanan pengunjung merupakan bagian dari melayani tamu yang sudah berkunjung ke Lombok. Selain itu pihak PHRI berkepentingan untuk mempertahankan jumlah kunjungan dimasa yang akan datang. Pelayanan terbaik akan memberi kesan baik pada wisatawan (Fauzi, 20l8).

\section{Penguatan Komunitas}

Kolaborasi dalam penanganan bencana memerlukan adanya jejaring antara lembaga pemerintah, swasta, dan Lembaga Swadaya Masyarakat (LSM). Kolaborasi ketiga elemen tersebut dapat mengurangi dampak gempa terutama kepada masyarakat. Pada masa sebelum bencana, para pihak mempersiapkan masyarakat setempat agar siap menghadapi bencana. Kemudian ketika bencana datang, penanganan bencana lebih banyak dilakukan oleh pihak lembaga yang sudah terlatih biasanya adalah lembaga negara. Ketika keadaan darurat sudah berakhir maka diperlukan lagi kolaborasi kelembagaan seperti sebelum terjadi bencana untuk memulihkan keadaan menjadi normal.

Penanganan sebelum terjadi bencana, lembaga lokal, swasta, dan pemerintah dapat membuat perencanaan untuk mengurangi dampak buruk dari bencana. Ketika berbicara masalah ekowisata maka lembaga lokal yang berada di lokasi menjadi kunci penggerak dalam membuat perencanaan. Lembaga lokal dapat bekerjasama dengan lembaga di tingkat yang lebih tinggi dalam menentukan langkah 
pencegahan terbaik yang dapat dilakukan di lokasi. Contoh dari kolaborasi ketiga elemen pemerintah, swasta, dan LSM, misalnya, lembaga pemerintah membuat jalur evakuasi pada wilayah rawan bencana, penginapanpenginapan di lokasi wisata membuat titik kumpul untuk antisipasi ketika bencana datang, dan LSM melatih keterampilan warga lokal untuk membuat aneka makanan dan lain sebagainya. Jaringan kolaborasi dapat dilihat dalam Bagan koordinasi pada Gambar 2. Karena tujuan akhir dalam kolaborasi penanganan bencana adalah komunitas yang mandiri dan mampu mengatasi segala kesulitan ketika bencana.

Perencanaan

juga berarti

menginventarisir sumber daya yang dapat digunakan secara maksimal ketika bencana datang. Dalam implementasi ketika terjadi bencana para pihak membutuhkan : monitoring, komunikasi dan kontrol yang efektif, pengalokasian sumberdaya yang efisien, dan kolaborasi dengan lembaga kunci dari tingkat terendah sampai dengan tingkat tertinggi (Ritchie, 2004). Koordinasi dan kolaborasi dapat dilakukan dengan membentuk tim yang rutin melakukan pertemuan untuk membahas respon sekaligus strategi dalam menghadapi kemungkinan terbaik yang dapat dilakukan untuk mengatasi bencana.

Kerjasama yang dilakukan tidak selalu sesuai dengan tugas pokok dan fungsinya, karena pada keadaan darurat tidak semua hal yang dibutuhkan dapat tersedia. Akan tetapi menjadi lebih baik jika lembaga-lembaga yang dibutuhkan sudah berdiri dan hanya melaksanakan sesuai dengan tugas pokoknya. Misalnya di Lombok Timur telah berdiri forum antar Lembaga daerah yang menangani kebencanaan, dan lembaga semacam ini juga sudah banyak berkembang di berbagai daerah di Indonesia seiring kesadaran daerah terhadap ancaman bencana.

Komunikasi bencana yang efektif dapat memberi informasi kepada pihak lain untuk terlibat dalam penanganan bencana. Pemberitaan tentang bencana sedapat mungkin dapat menarik simpati masyarakat dan para pihak lain yang memiliki sumber daya dan walaupun tidak berkaitan langsung dengan bidangnya. Informasi yang tepat akan menurunkan dampak negatif dari isu yang selama bencana belangsung dan berkembang.

Misalnya ketika terjadi gempa Pulau Lombok muncul isu terjadinya penjarahan bantuan oleh oknum masyarakat, hal tersebut akan menyurutkan keinginan masyarakat di tempat lain atau para pihak yang sudah berniat untuk membantu korban bencana.

Jika berbicara mengenai pariwisata maka yang berhak untuk memberi penilaian tentang kondisi wisata adalah lembaga kunci di bidang pariwisata seperti Kementerian Pariwisata atau instansi vertikalnya, pengelola objek wisata misalnya Balai Taman Nasional Gunung Rinjani yang mengelola Taman Nasional, dan kelompok sadar wisata (Pokdarwis).

Namun yang tidak kalah penting adalah koordinasi antara wisatawan dan masyarakat lokal dapat mengurangi kepanikan ketika terjadi bencana. Kepemimpinan diperlukan dalam menggerakan sumber daya baik manusia maupun non manusia. Kepemimpinan yang baik ketika terjadi bencana akan membangun kepercayaan dari para pihak yang terkait agar dapat terlibat dalam penanganan darurat krisis. Pariwisata adalah bisnis yang melibatkan banyak pihak mulai dari tingkat lokal sampai dengan tingkat nasional yang masing-masing tingkat memiliki struktur organisasi yang beragam. 


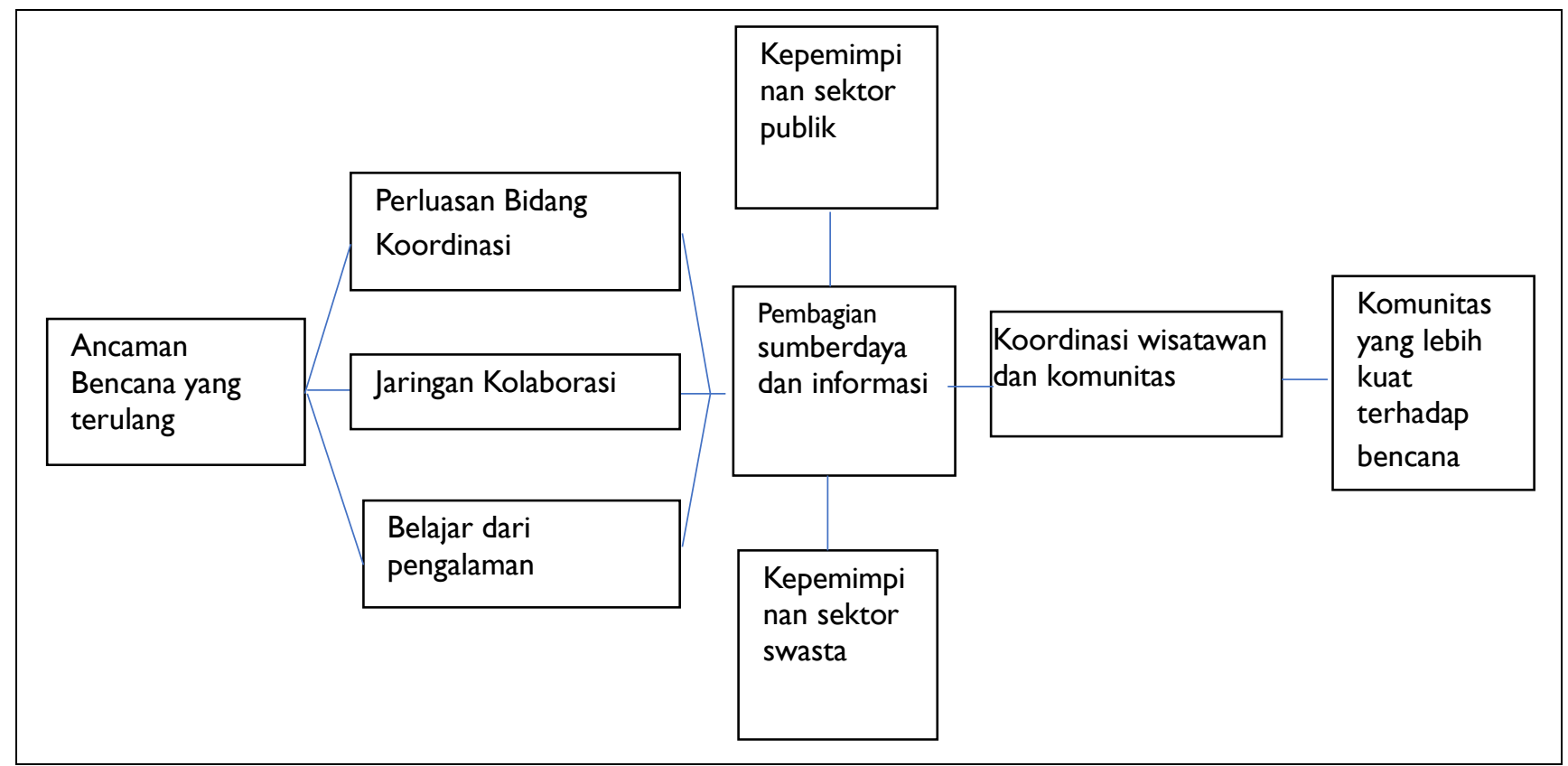

Sumber : Kapucu (2008), dan Pennington-Gray. et.al (2015)

Sources : Kapucu (2008), and Pennington-Gray. et.al (20I5)

\section{Gambar 2. Koordinasi dan respon pada bencana \\ Figure 2. Coordination and responses to disasters}

Kepemimpinan pada berbagai bidang para pihak dapat bersatu membahas kemungkinan yang dapat dilakukan dengan mengumpulkan sumber daya yang ada pada masing-masing para pihak (Gambar 2), sehingga nantinya terbentuk koordinasi antar para pihak yang terjalin baik. Para pihak tingkat nasional yang lebih kuat sumber dayanya membutuhkan pemangku kepentingan di tingkat lokal yang lebih kecil sumber dayanya.

Pola hubungan kemitraan yang besar membantu yang kecil menjadi salah satu bagian dalam penanganan bencana, misalnya dukungan pendanaan ketika masa tanggap darurat. Kepemimpinan secara umum dipegang oleh BNPB yang menjadi koordinator institusi di daerah. Akan tetapi untuk sektor pariwisata akan lebih baik jika lembaga kepariwisataan menangani di wilayah pariwisata terutama ketika rehabilitasi dan rekonstruksi.

\section{KESIMPULAN DAN KELEMAHAN}

\section{A. Kesimpulan}

Dari pembahasan di atas dapat disimpulkan bahwa kolaborasi yang melibatkan banyak pihak dalam penanggulangan bencana sangat diperlukan untuk mengurangi dampak buruk gempa bumi di Pulau Lombok terhadap sektor pariwisata. Penanganan bencana diawali dari perencanaan yang matang, dan ketika bencana datang sehingga penanganannya menjadi mudah dilakukan. Kolaborasi antar para pihak terutama pemerintah, swasta, dan LSM dalam membentuk masyarakat yang tangguh dengan bencana menjadi penting untuk dilakukan. Pada tahap pre-event atau masa sebelum bencana datang, lembaga lokal baik masyarakat, pemerintah, dan lembaga swadaya masyarakat banyak berperan dalam mitigasi atau pencegahan. Namun ketika bencana 
terjadi, kekuatan sumberdaya untuk evakuasi dititikberatkan pada lembaga pemerintah seperti TNI, POLRI, BASARNAS, BNPB, PMI, lembaga kesehatan, dan lain sebagainya. Sedangkan pada tahap pemulihan, Kementerian Pariwisata dan Balai Taman Nasional Gunung Rinjani memiliki peran dalam menormalkan kembali pariwisata di wilayah Taman Nasional Gunung Rinjani pascabencana.

\section{B. Kelemahan}

Penelitian ini memiliki kekurangan yaitu hanya menggunakan data online. kemungkinannya, masih terdapat para pihak lain namun tidak tercantum dalam hasil penelitian. Hal ini dikarenakan, pencarian data menggunakan mesin pencari dapat berubah tergantung jenis mesin pencari, lokasi ketika mengakses internet, waktu pencarian, dan penurunan kualitas website. Untuk itu penelitian berikutnya dapat mengisi kekurangan dengan melakukan konfirmasi langsung secara offline kepada para pihak yang terlibat dalam penanganan bencana.

\section{DAFTAR PUSTAKA}

Anisa, S. (2019, 12 Januari). BNPB: Seribu Pendaki Diselamatkan, Evakuasi di Rinjani Selesai. Diambil dari news.detik.com: https://news.detik.com/berita/4 I4302I/bnp b-seribu-pendaki-diselamatkan-evakuasi-dirinjani-selesai

bakti.or.id. (2019, 5 Januari). Menangani Bencana di Kaki Rinjani. Diambil dari bakti.or.id: http://praktikcerdas.bakti.or.id/project/men angani-bencana-di-kaki-rinjani/

bbc.com. (2018, 5 Desember). Gempa Lombok: Sebanyak 1.226 pendaki telah dievakuasi dari Gunung Rinjani. Diambil dari bbc.com: https://www.bbc.com/indonesia/indonesia$\underline{45002319}$

BNPB. (2019, 12 Januari). Tugas dan Fungsi BNPB.
Diambil dari bnpb.go.id: https://bnpb.go.id/home/tugas

cnnindonesia.com. (2018, 7 Desember). Kemenpar Siapkan 3 Skenario Penanganan Bencana. Diambil dari cnnindonesia.com: https://www.cnnindonesia.com/gayahidup/20171004132828-307-

246032/kemenpar-siapkan-3-skenariopenanganan-bencana

Corti, L., \& Fielding, N. (2016). Opportunities From the Digital Revolution: Implications for Researching, Publishing, and Consuming Qualitative Research. SAGE Open, I-I3.

Dimyati, V. (2019, 2I Maret). Mitigasi Bencana Kurangi Risiko pada Dunia Pariwisata, Ini Kata Menpar. Diambil dari inews.id: https://www.inews.id/travel/destinasi/mitig asi-bencana-kurangi-risiko-pada-duniapariwisata-ini-kata-menpar/473157

Dougall, E. K., Horsley, J. S., \& McLisky, C. (2008). Disaster Communication: Lessons from Indonesia. International Journal of Strategic Communication , 75-99.

Evan, W. M. (1965). Toward a Theory of InterOrganizational Relations. Management Science, B2 17-B230.

Fauzi, M. P. (2018, 5 Desember). Prioritaskan Tamu, RI Banjir Pujian saat Evakuasi Turis di Rinjani. Diambil dari detik.com: https://travel.detik.com/travel-news/d-

4148283/prioritaskan-tamu-ri-banjirpujian-saat-evakuasi-turis-di-rinjani

Freeman, E. (2010). Strategic Management: A Stakeholder Approach. Cambridge: Cambridge University Press.

Inpres No 5 Tahun 2018. (tanpa tanggal.). Tentang Percepatan Rehabilitasi Dan Rekonstruksi Pascabencana Gempa Bumi Di Kabupaten Lombok Barat, Kabupaten Lombok Utara, Kabupaten Lombok Tengah, Kabupaten Lombok Timur, Kota Mataram, Dan Wilayah Terdampak Di Provinsi Nusa Tenggara Barat. Iswidodo. (2019, II Januari). Indonesia Berada di Titik Pertemuan Tiga Lempeng Aktif. Diambil dari 
http://jateng.tribunnews.com

/2018/10/02/indonesia-berada-di-titik-

pertemuan-tiga-lempeng-aktif:

http://jateng.tribunnews.com/2018/10/02/i

ndonesia-berada-di-titik-pertemuan-tiga-

lempeng-aktif

Jania. (2019, 5 Januari). Merajut Kesiapsiagaan

Menuju Ketangguhan. Diambil dari

oxfamblogs.org:

https://oxfamblogs.org/indonesia/merajut-

kesiapsiagaan-menuju-ketangguhan/

Kapucu, N. (2008). Collaborative emergency management: better community organising, better public preparedness and response. Disaster, 239-262.

Kementerian Pariwisata RI. (2019, 21 Maret). Kedudukan, Tugas dan Fungsi Kementerian Pariwisata. Diambil dari www.kemenpar.go.id:

http://www.kemenpar.go.id/asp/detil.asp?c $=7 \& \mathrm{id}=2899$

Kurniawan, I. (2019, 12 Januari). Pariwisata NTB Kian Pikat Masyarakat Singapura. Diambil dari neraca.co.id:

http://www.neraca.co.id/article//0846I/Par iwisata-NTB-Kian-Pikat-Masyarakat-

Singapura

liputan6.com. (20I8, I I November). Kemenpar Siap

Pulihkan Pariwisata Lombok. Diambil dari liputan6.com:

https://www.liputan6.com/lifestyle/read/36

32896/kemenpar-siap-pulihkan-pariwisatalombok

mongabay.co.id. (2018, 19 November). Gunung Rinjani Kemungkinan Dibuka 2020, Hasil Survei Menunjukkan Kondisi Masih Rawan. Diambil dari mongabay.co.id: http://www.mongabay.co.id/2018/I0/21/gun ung-rinjani-kemungkinan-dibuka-2020hasil-survei-menunjukkan-kondisi-masihrawan/

Pennington-Gray, L., Cahyanto, I., Scroeder, A., \& Kesper, A. (20I5). Collaborative Communication Networks: An Aplication in Indonesia. In B. W. Ritchie, \& K.
Campiranon, Tourism Crisis and Disaster Management in the Asia-Pacific (pp. 77-96). Oxfordshire: $\mathrm{CABI}$.

Rachman, F. F. (2019, I4 Maret). BNPB Prediksi Kerugian Gempa NTB Naik Jadi Rp 8,8 Triliun. Diambil dari news.detik.com: https://news.detik.com/berita/4184658/bnp b-prediksi-kerugian-gempa-ntb-naik-jadirp-88-triliun

Reza. (2019, 12 Januari). Kemenpar Siap Pulihkan Pariwisata Lombok. Diambil dari liputan6.com:

https://www.liputan6.com/lifestyle/read/36 32896/kemenpar-siap-pulihkan-pariwisatalombok

Ritchie, B.W. (2004). Chaos, Crisis and Disaster: a strategic aproach to crisis management in the tourism industry. Tourism Management, 669-683.

Senja, A. M. (2019, 12 Januari). Pasca-Gempa Lombok, TN Gunung Rinjani Akan Kaji Potensi Wisata Alternatif. Diambil dari travel.kompas.com: https://travel.kompas.com/read/2018/08/08 III1000927/pasca-gempa-lombok-tngunung-rinjani-akan-kaji-potensi-wisataalternatif

Soenarso, S. A. (2019, 12 Januari). Kempar targetkan pemulihan wisata Lombok kurang dari tujuh bulan. Diambil dari lifestyle.kontan.co.id: https://lifestyle.kontan.co.id/news/kempartargetkan-pemulihan-wisata-lombokkurang-dari-tujuh-bulan

suarantb.com. (2018, 19 November). Dampak Gunung Agung, Gili Trawangan Terlihat Lengang. Diambil dari uarantb.com: https://www.suarantb.com/gaya.hidup/pari wisata/2017/I I/249485/Dampak.Gunung.A gung,Gili.Trawangan.Terlihat.Lengang/

Undang-Undang Nomor 24 Tahun 2007 Tentang Penanggulangan Bencana

Wang, Z., \& Ye, X. (20I7). Social Media Analytics for Natural Disaster Management. International Journal of Geographical Information Science, 49-72. 
Jurnal FALOAK Vol. 3 No.l April 2019: 15-28 